Article

\title{
Towards Understanding the Source of Brine Mineralization in Southeast Nigeria: Evidence from High-Resolution Airborne Magnetic and Gravity Data
}

\author{
Stephen E. Ekwok ${ }^{1}$, Anthony E. Akpan ${ }^{1}$, Ogiji-Idaga M. Achadu ${ }^{2}$, Cherish E. Thompson ${ }^{1}$, Ahmed \\ M. Eldosouky ${ }^{3, *}$, Kamal Abdelrahman ${ }^{4}$ and Peter Andráš 5
}

check for

updates

Citation: Ekwok, S.E.; Akpan, A.E.; Achadu, O.-I.M.; Thompson, C.E.; Eldosouky, A.M.; Abdelrahman, K.; Andráš, P. Towards Understanding the Source of Brine Mineralization in Southeast Nigeria: Evidence from High-Resolution Airborne Magnetic and Gravity Data. Minerals 2022, 12, 146. https://doi.org/10.3390/ $\min 12020146$

Academic Editor: Frank Wendler

Received: 11 December 2021

Accepted: 24 January 2022

Published: 25 January 2022

Publisher's Note: MDPI stays neutral with regard to jurisdictional claims in published maps and institutional affiliations.

Copyright: (c) 2022 by the authors. Licensee MDPI, Basel, Switzerland. This article is an open access article distributed under the terms and conditions of the Creative Commons Attribution (CC BY) license (https:// creativecommons.org/licenses/by/ $4.0 /)$.
1 Applied Geophysics Programme, Department of Physics, University of Calabar, Calabar 540271, Nigeria; styvnekwok@unical.edu.ng (S.E.E.); anthonyakpan@unical.edu.ng (A.E.A.); cherishthompson@unical.edu.ng (C.E.T.)

2 Department of Geology, University of Calabar, Calabar 540271, Nigeria; martinsachadu@unical.edu.ng

3 Department of Geology, Suez University, Suez 43518, Egypt

4 Department of Geology \& Geophysics, College of Science, King Saud University, Riyadh 11451, Saudi Arabia; khassanein@ksu.edu.sa

5 Faculty of Natural Sciences, Matej Bel University in Banska Bystrica, 97401 Banska Bystrica, Slovakia; peter.andras@umb.sk

* Correspondence: ahmed.eldosouky@sci.suezuni.edu.eg; Tel.: +20-115-326-7202

\begin{abstract}
Investigation into understanding the genesis of brines in southeast Nigeria was carried out utilizing high-resolution potential field (HRPF) data. This study reveals that igneous intrusions and associated hydrothermal fluids are responsible for brine generation. The obtained result of the analytic signal revealed the locations and spatial distribution of short- and long-wavelength geologic structures associated with igneous intrusions. The low pass filtering, upward continuation, and 2D modelling procedures showed key synclinal structures which coincided well with the location of brine fields. The results showed that salt ponds are common in the neighborhood of igneous intrusions. To validate this finding, a conceptual model describing igneous-related hydrothermal circulation systems that are driven by convective cells of the hydrothermal fluid and overburden loads was generated. This model fits reasonably well into the overall stratigraphic and geologic framework of the study area.
\end{abstract}

Keywords: magnetic method; gravity method; magmatic intrusion; hydrothermal fluid; Lower Benue Trough; southeast Nigeria

\section{Introduction}

Since the early twentieth century, the origin of brine fields in the Benue Trough and adjacent sub-basins has been a point of contention [1,2]. Brines can be found in ponds, springs, drilled water boreholes, and hand-dug wells [3]. In terms of their genesis in the Benue Trough (BT), [3,4] summarized three possibilities proposed by previous studies. They include formation or a connate water source [5-7], evaporite or a solid source [8-10], and a hydrothermal source [8-14]. Most of the prior studies have been focused on a single occurrence or projections, and some lack relevant hydro-chemical data [3]. In general, these studies determined that the brines in the Trough came from either connate water or evaporite.

Hydro-geochemical investigation of the Middle and Lower Benue Trough reveals that brines are the result of halite dissolution and fossil seawater sources [4]. In [15,16], the authors conducted similar research that linked brines to a marine source. In [17], on the other hand, the authors suggested that connate water was the primary source of brines in the BT. Although [1] suggested an evaporite source, [4] stated that "there was no proof of evaporites in the BT". In the western Qaidam basin, meteoric water was identified as 
the main source of saltwater [18], while [19] identified meteoric, carbonate, and magmatic waters as the different sources of brines in the Sichuan basin.

Recent studies by [20-25] show that hydrothermal processes play a powerful role in the generation of brines within and beyond rift environments dominated by intrusive and extrusive rocks. Hydrothermal fluid igneous-related hydrothermal circulation systems with high salinity are highly mineralized, containing dissolved minerals such as zinc, lead, gold, and copper $[20,22,25]$ The BT is the main target of geoscience research due to its mineralization, complicated tectonics, and associated geologic features $[4,26,27]$. Field observations, hydro-geochemical, isotopic, and geomorphic features, as well as tectonic and stratigraphic investigations, revealed the presence of brine fields, barite-lead-zinc veins, and fracture systems in the vicinity of magmatic intrusions in the BT [3,4,28-30].

Magnetic and gravity data can be used to investigate magmatism and its associated structures. Potential field datasets can be applied to delineate deep-seated faults [31-34], basement relief [35,36], intrusive granitoids [37,38] and geological structures [39]. Intrusions and geologic features are defined as the driving mechanisms for mineralization [20]. For instance, numerous geophysical techniques allow for a quick exploration of nearsurface volcanics and intrusive rock adjacent to salt ponds in the BT [3]. Mineralization is frequently linked to hydrothermal alterations and structural control produced by magmatic intrusions $[25,40]$. High-resolution airborne magnetic and gravity measurements are now considered essential components of mineral exploration [40,41]. Magnetization and density discrepancies induced by igneous-related hydrothermal occurrences can be mapped using this information.

The aeromagnetic method is an appropriate and effective mineral assessment tool wherever there are magnetization variations between rock types [42-46]. Enhanced magnetic data can delineate fractures, faults, dykes, rock boundaries, and even regional surficial geologic contacts [47-53]. A pseudo-geological map can be built using magnetic data from which prospective mineralization zones can be inferred [54,55]. Similarly, gravity data can reveal the shape of magmatic intrusions and related geologic structures beneath the surface, map sedimentary basins, and provide vital information on basin formation mechanisms [56]. The gravity method is commonly operated as a control in seismic studies and as a tool in petroleum development [41]. It can also be used in hydrogeological, archaeological, and engineering studies $[57,58]$. Furthermore, in joint base metal investigations, the technique is often applied to specified targets delineated by magnetic and electromagnetic investigations $[41,59,60]$.

This study uses gravity and magnetic data to look for anomalies connected to igneousrelated hydrothermal circulation systems, brine field locations, and structures within the Ikom-Mamfe-Rift and Abakaliki Anticlinorium in the Lower Benue Trough (LBT). Researchers have discovered that areas with tectonothermal activity and hydrothermal changes frequently have different magnetic and density properties compared with nearby areas of comparatively free igneous intrusions [61-63]. Some geophysical investigations of brines and associated lead-zinc-barite ( $\mathrm{Pb}-\mathrm{Zn}-\mathrm{Ba}$ ) mineralization in the $\mathrm{BT}$ used electromagnetic, electrical resistivity, and ground gravity methods [17,53,64-67] The genesis of brine fields in southeast Nigeria is investigated using high-resolution potential field (HRPF) data. In addition, the genetic environment of these brines is explored with regard to the research area's geo-tectonic setting. Image analysis, enhancement procedures, and 2D modeling involving HRPF data are applied to delineate the hydrothermally altered zones and locate some geologic structures, possible locations of intrusions, and brines.

\section{Geologic Setting of the Study Area}

\subsection{Location}

The area of investigation is situated in southeast Nigeria (Long. $7^{\circ} 30^{\prime} \mathrm{E}$ to $9^{\circ} 00^{\prime} \mathrm{E}$ and Lat. $6^{\circ} 00^{\prime} \mathrm{N}$ to $6^{\circ} 30^{\prime} \mathrm{N}$ ). The elevation above sea level map (Figure 1) of the studied region shows that the altitudes varied, starting approximately $29.4-186.5 \mathrm{~m}$ above sea level, with the eastern and northwestern parts having maximum heights. 


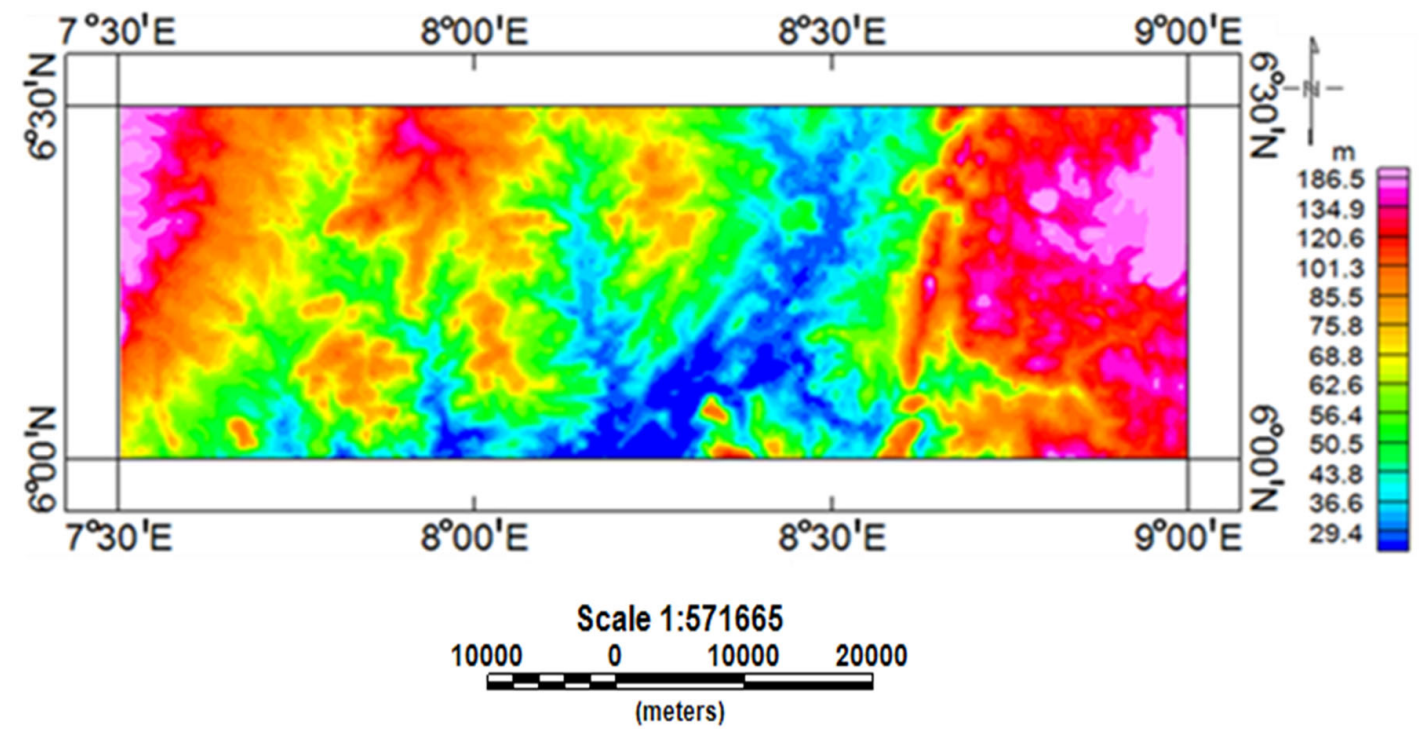

Figure 1. Elevation (above sea level) map of the study location.

\subsection{Geology}

The study area covers some geologic regions of the Abakaliki Anticlinorium (AA), Ikom-Mamfe Rift (IMR), and Obudu Plateau (OP) (Figure 2). The OP occupies the northeastern flank. It is edged in the west by AA and southeast by IMR. The IMR which intruded the study territory at the southeastern flank is bounded by the AA in the west, northwest, and north, and the OP in the northeast. The AA occupies southwestern, western, northwestern, and northern domains.

The Bamenda Massif is an extension of the OP, which is one of the Nigerian basement outcrops in southeast Nigeria $[68,69]$. The region's lithological differences include highgrade metamorphic rocks, primarily gneisses, and schists, intruded by un-metamorphosed dolerites, granites, aplites, and quartzo-feldspathic veins, and they are heavily migmatized [68]. Rocks from this area have been dated to be Eburnean, Archaean, and Pan-African in age [70]. Workers concluded that the evolutionary history of the southeast basement in Nigeria is related to the mobile Pan-African belt in central Africa, after comparing the lithologies and ages of rocks from the central African Fold Belt, northern Cameroon, and southeast Nigeria basement complexes [68,70]. The Pan-Central-African belt is the result of a continent-continent collision, with the Congo craton's northern edge acting as a passive margin, while the western Cameroon domains and Adamawa-Yade acted as active margins $[2,68]$. The OP is associated with migmatitic gneisses, which are classified as garnet-hornblende gneiss, garnet-sillimanite gneiss, or simply migmatite gneiss [68,71]

The IMR is an eastern extension of the Lower Benue Trough that runs into Cameroon, and terminates below the Tertiary-Recent cover of the Cameroon Volcanic Line (CVL) [72]. Igneous intrusions in the IMR, which were caused by Tertiary-Recent tectonic processes related to the CVL, resulted in extensive deformations and metamorphisms of the geologic materials in the region. As a result, the covering sedimentary sequences became severely fractured, baked, deformed, and domed [63].

The Asu River Group (ARG), which includes conglomeratic sandstones, conglomerates, mudstones, shales, calcareous, and carbonaceous rocks, is the first sedimentary group in the IMR [73]. The ARG sits on highly fractured Precambrian basement rocks [73]. The Eze-Aku Formation (EAF) was deposited during the Turonian regression period. The postSantonian Nkporo-Afikpo Shale Formation overlies the EAF. The sandstone, mudstone, and shale strata are the foremost rock components of this formation [29]. 


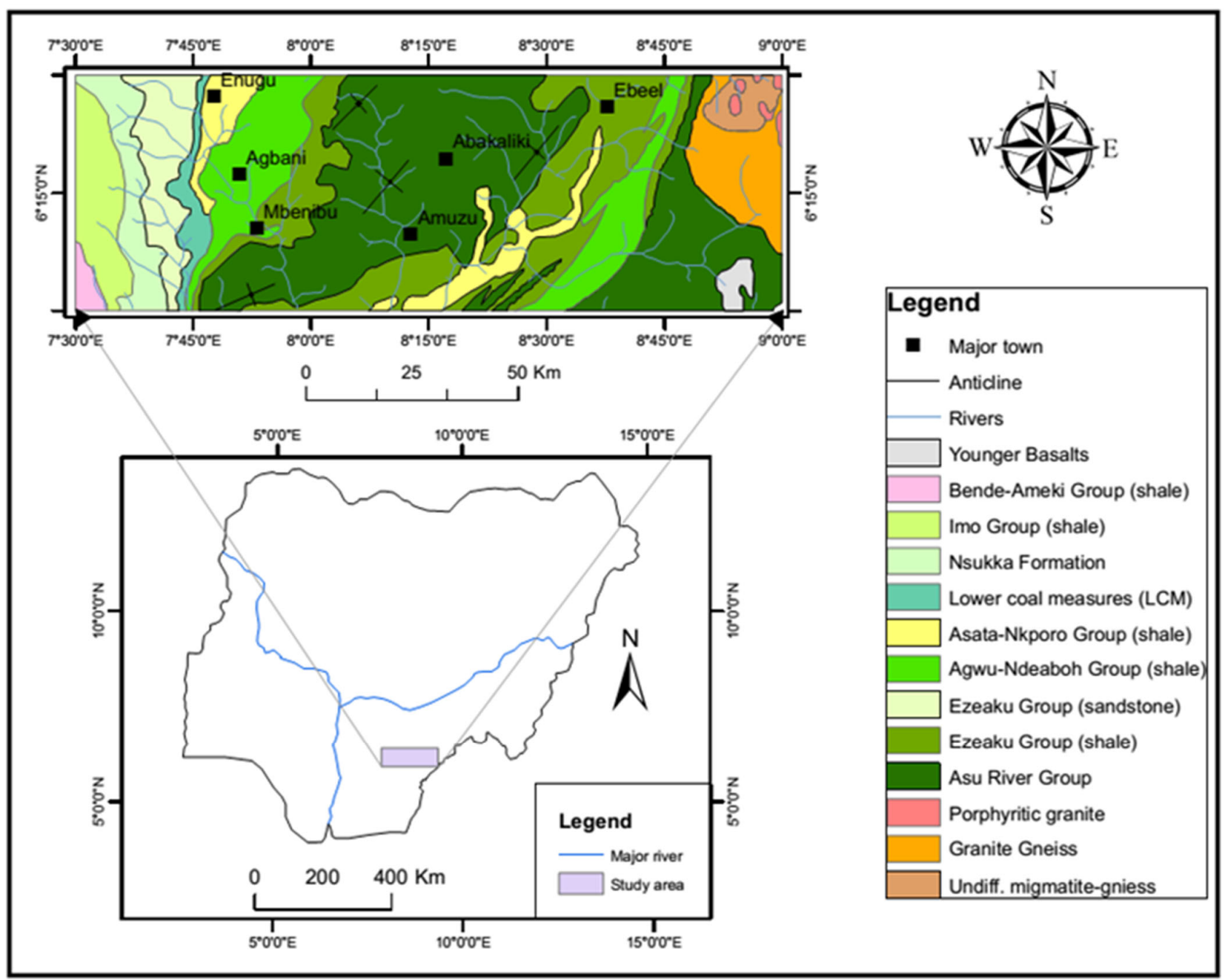

Figure 2. Geologic map of the study location.

The Campanian Nkporo Shale, Coniacian Awgu Shale, Turonian Eze-Aku Shale, and Albian Asu River Group are among the strata found in the AA [74]. The Albian ARG is made up of fissile, heavily fractured, bluish-black shales with very few sandstone strata [74]. The EAF is made up of calcareous sandstones, calcareous siltstones and shales, and thin sandy and shelly limestones [75]. Grey bluish shales, marine fossiliferous limestones, and calcareous sandstones from the Coniacian period make up the Awgu Shales [74]. The Awgu Shales are overlain by the Campanian Nkporo Shales, which are predominantly marine with some arenaceous sandstone units (Figure 3).

The folding of the overlying layers was caused by massive Santonian tectonic processes that occurred in two periods [29,74]. The Abakaliki Anticlinorium arose from the dominantly compressional nature of the forces. In [76], the authors compared the geological development of the Abakaliki province to that of a complete orogenic cycle encompassing sedimentation, magmatism, metamorphism, and compressive tectonics in thorough research on the geology of the province. According to [76], the compression that caused the large-scale folding and cleavage was directed at $\mathrm{N} 155^{\circ} \mathrm{E}$. As a result of the magmatism, multiple intrusive masses were injected into the Eze-Aku and Asu River Group shales [74]. 


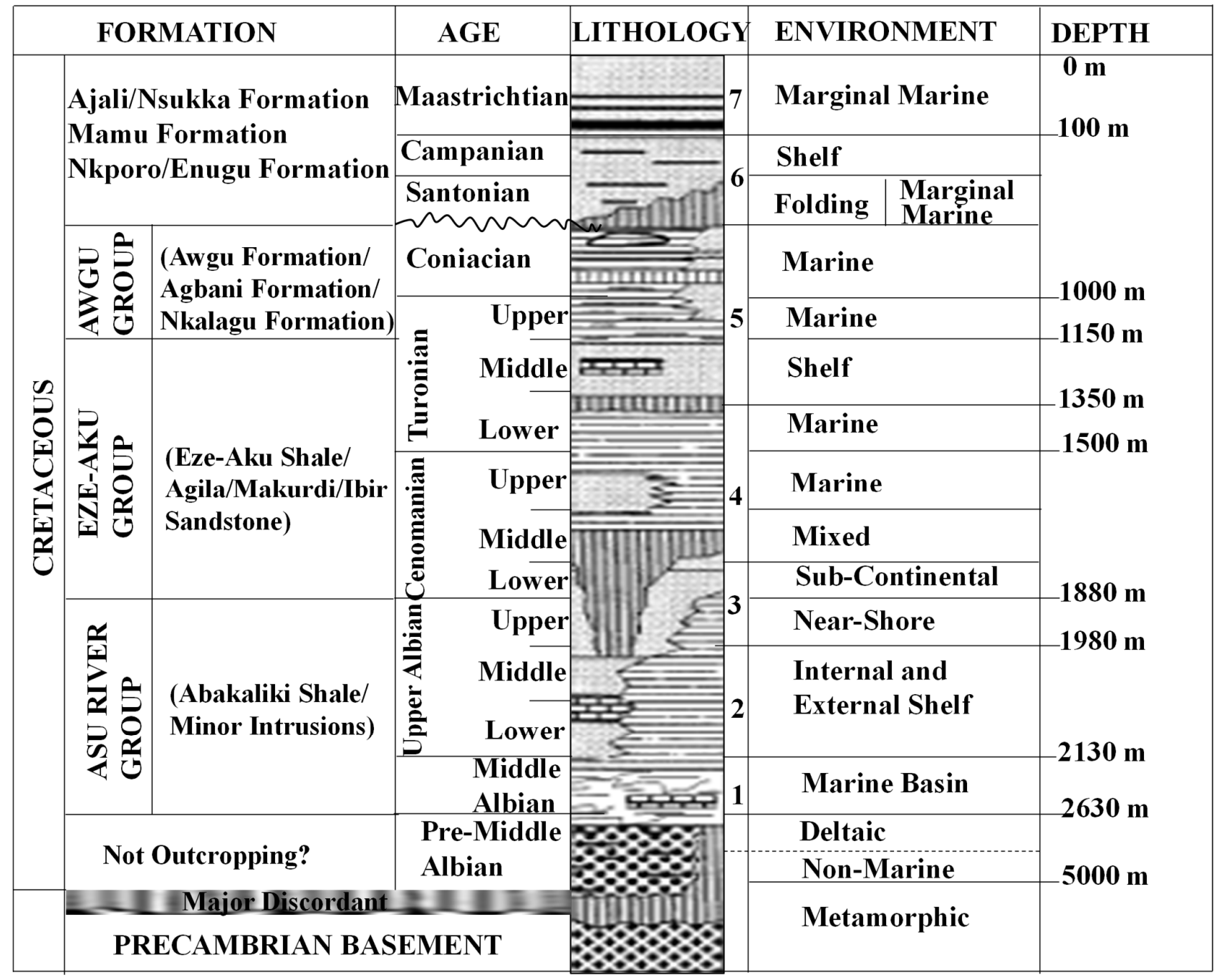

Figure 3. Lithostratigraphic sequence of the Lower Benue Trough.

\section{Materials and Method}

3.1. Data Acquisition

The Nigerian Geological Survey Agency (NGSA) provided the airborne gravity and magnetic data used in this investigation. Between 2005 and 2010, Fugro Airborne Surveys, Canada, measured, reduced, and compiled the high-resolution geophysical datasets, which were then submitted to the NGSA in digitized and gridded forms. The data were collected along 826,000 lines using the Flux-Adjusting Surface Data Assimilation System (FASDAS) with tie-line spacing, flight-line spacing, and terrain clearance of $0.5 \mathrm{~km}, 0.1 \mathrm{~km}$, and $0.08-0.1 \mathrm{~km}$, respectively.

The tenth (10th) generation of the International Geomagnetic Reference Field (IGRFversion 4.0) and International Gravity Standardization Net 1971 (IGSN71) algorithms were used to subtract regional fields from observed HRPF data. The IGSN71 and IGRF, both of which are widely used and approved, provide consistency in potential field exploration techniques [69]. The employed HRPF data in this study were reduced and processed to total magnetic intensity (TMI) and Bouguer gravity gridded (BG) maps (Figure 4). 


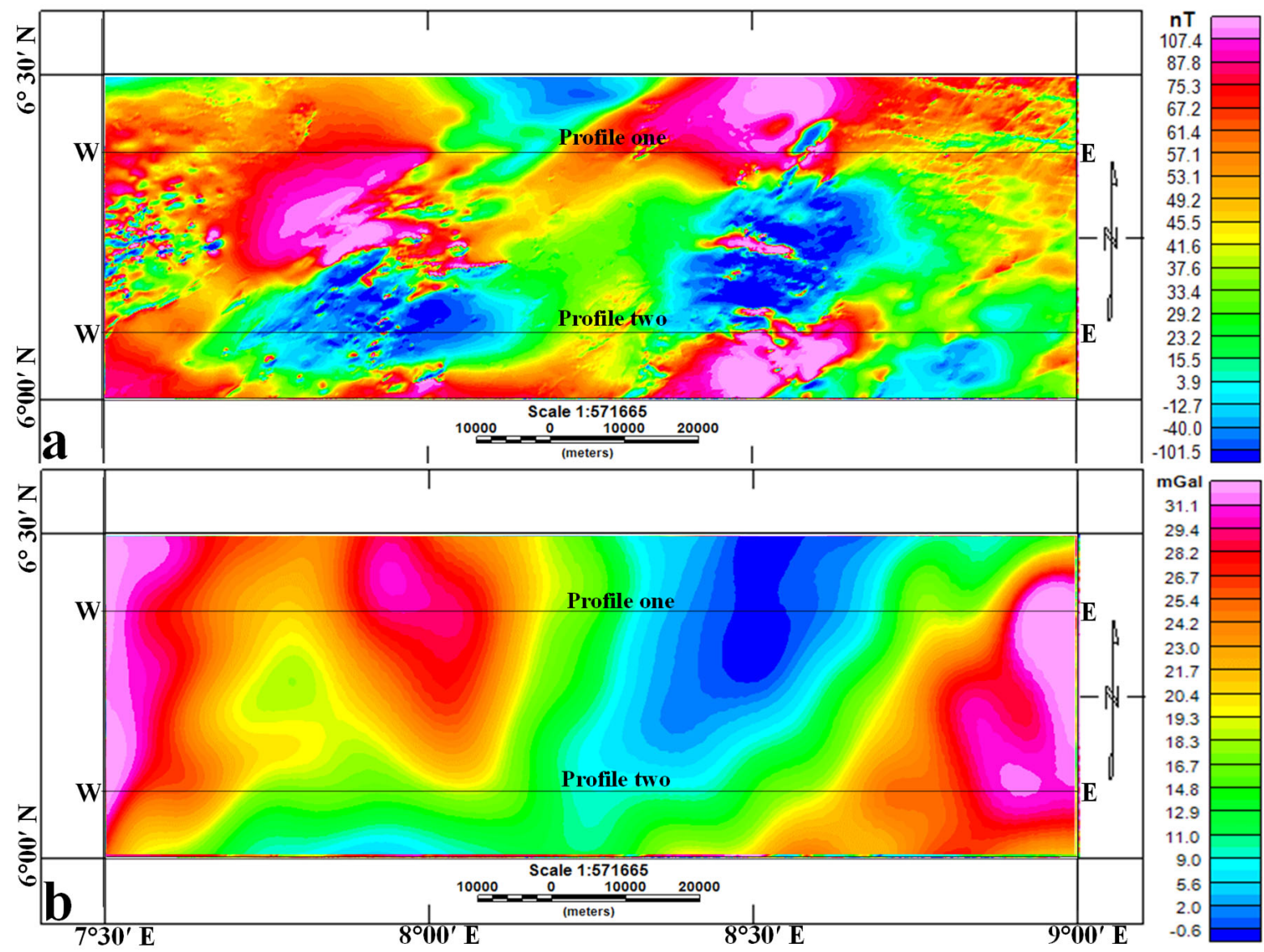

Figure 4. (a) Total magnetic intensity and (b) Bouguer gravity maps (with profiles 1 and 2 used for modelling).

\subsection{Methodology}

Local datum transformation and projection technique were used to record the potential field data in the World Geodetic System 84 (WGS-84) and Universal Transverse Mercator coordinate system at zone 32 of the northern hemisphere (UTM-32N). Using the Oasis montaj "add grid" menu, the gridded data were loaded into the toggle project explorer platform. The data were loaded into the MAG-MAP, source parameter imaging (SPI), Euler deconvolution, and GM-SYS tools, which generated control files for the various enhancement and modelling methods.

Filtering algorithms deliberately enhance anomalies from a certain set of geologic sources relative to anomalies due to other geologic sources and they are used in potential field data enhancements [77]. The main igneous intrusions in the research area were delineated using typical potential field (PF) data enhancement methods such as the analytic signal (ASig) [78-81], low pass filter [82], and upward continuation (UPWC) method [53,54]. In addition, 2D forward modelling was operated to map igneous intrusions, estimate sediment thicknesses, and define basement topography.

The ASig filter [83,84] generates maximum responses over magnetic/gravity anomalies and detects the edges of magnetic/gravity source bodies. This filter is commonly applied at low-magnetic latitudes due to the in-built complication associated with the RTP technique. The most important advantage of the analytical signal is that, in 2D cases, it does not depend on the direction of magnetization, but this is incorrect in 3D case [78]. In [78], the 
authors demonstrated that the ASig amplitude can be obtained from the three orthogonal derivatives of the potential field as:

$$
\left|\operatorname{ASig}_{(x, y)}\right|=\sqrt{\left(\frac{\partial A}{\partial x}\right)^{2}+\left(\frac{\partial A}{\partial y}\right)^{2}+\left(\frac{\partial A}{\partial z}\right)^{2}}
$$

where, $A$ is the measured PF.

The low pass filter is based on the method proposed by [82], and the filter cut-off wavelength is the only variable parameter [85]. Although it passes low-frequency signals, and weakens signals with frequencies above the cut-off frequency, low-pass filtering is used to eliminate unwanted short-wavelength anomalies [86]. The rectangular low-pass filter in a 1D Fourier transform is provided by:

$$
L(k)=\left\{\begin{array}{l}
1, k \leq k_{c} \\
0, k>k_{c}
\end{array}\right.
$$

where $L(k)$ is the amplitude spectrum of the transfer function of the rectangular filter and $k_{c}$ is the cut-off frequency.

In analyzing regional magnetic/gravity structures originating from deep-seated PF sources, UPWC is used. The upward continuation filter transforms the observed magnetic/gravity field on a surface to a higher level. In comparison to deep causative sources, this enhancement reduces the effect of near-surface bodies [53]. The wavenumber domain approach for UPWC [41] is expressed as follows:

$$
F(\omega)=e^{-h \omega}
$$

where, $h$ is the height of continuation. This procedure decreases progressively with increasing wavenumber, reducing the higher wavenumbers more severely, thus generating a map in which more regional anomalies predominate [87]. The 2D modelling method involves developing a geologic hypothetical model and computing magnetic/gravity responses, applying [88-90]. Every crustal block has a certain susceptibility and/or density value. The anomaly across the entire profile is the sum of all the crustal block contributions. The interpretation of PF anomalies is based on identifying the probable structures, locations, and physical properties of the geologic features that created the anomaly. Two profiles in the east-west direction were obtained from the TMI and BG data. The PFs for the sedimentary top and basal basement structural cross-section were estimated iteratively until acceptable matches between the observed and synthetic curves were achieved. Using programs found in Oasis montaj version 7.0.1 (OL), potential field data enhancement, automatic depth estimation, and 2D forward modelling operations were carried out (2008). The inverse problem normally associated with potential field data is ill-posed thus making the solution unstable and non-unique $[27,91]$. A consistent solution for such a problem can be acquired by having sufficient geologic knowledge and the use of improved techniques in data corrections, enhancements and interpretations [92].

Tight folds, cleaves, and igneous intrusions such as basic sills and sub-volcanic intrusions characterize the Cretaceous depositions in the study area [93]. In the Middle and Lower Benue Trough, [3] documented shallow volcanics and intrusions in the vicinity of salt ponds. PF methods can be operated to investigate magmatic intrusions, mineralization, and related geologic structures [8,20,43]. Enhanced PF data showed variable gravity and magnetic disparities from numerous causative sources caused by short- and long-wavelength anomalies [31]. According to [27], mineralization is typically associated with locations characterized by complex geologic formations, created by tectonic processes. Low-frequency structures on the improved maps were greatly highlighted to demarcate areas marked by long-wavelength anomalies. To map the main tectonics and depocenters in the research area, these anomalies were mapped using ASig, low pass, and UPWC filters. 


\section{Results}

The highest and lowest magnetic (pink $=0.0891 \mathrm{nT} / \mathrm{m}$ and blue $=0.0026 \mathrm{nT} / \mathrm{m}$ ) and gravity (pink $=0.00215 \mathrm{mGal} / \mathrm{m}$ and blue $=0.00040 \mathrm{mGal} / \mathrm{m}$ ) intensities can be easily identified (Figure 5). The eastern section of the investigated area (Figure 5) is dominated by basement biotite-gneiss and granite rocks of OP, where Kakube, Iso-Bendegheg, and Odumekpang fall. This region is characterized by basement rocks. They are believed to be the principal origin of high magnetization and density observed in the OP. Edor, Obubra, and Agbaragba regions that correspond with IMR have high magnetization and density believed to be caused by the Tertiary-Recent igneous intrusions related to the CVL [63]. Sparsely distributed high, moderate, and low potential field signatures occupy the remaining parts of the investigated area. This region is part of the AA, which is characterized by a post-depositional tectonic event [27]. Low gravity and magnetic strengths are also present in isolated locations denoted by various blue colors (indicating depocenters).
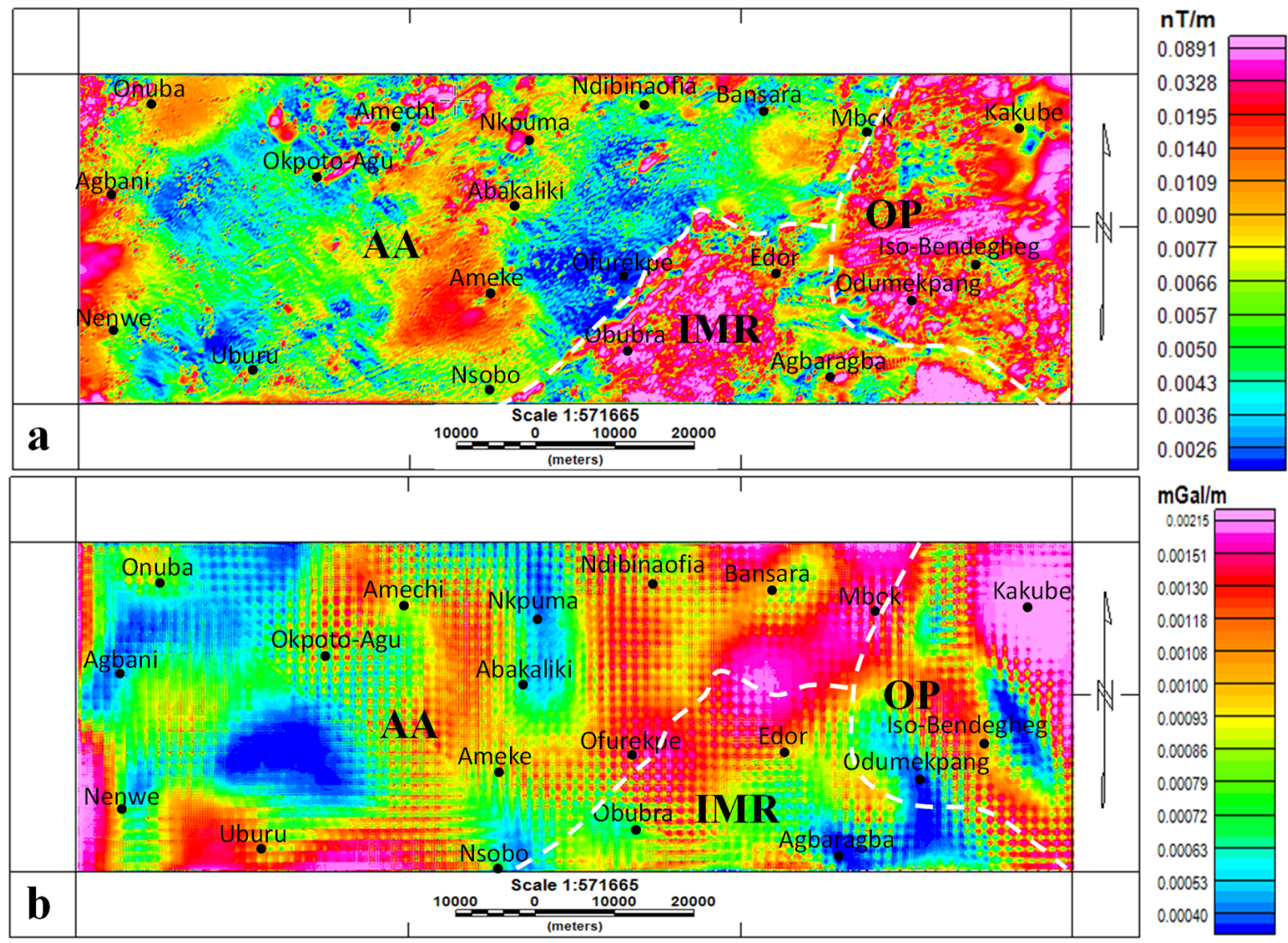

Figure 5. Analytic signal maps of (a) total magnetic intensity and (b) Bouguer gravity data. AA: Abakaliki Anticlinorium, OP: Obudu Plateau, IMR: Ikom-Mamfe Rift.

The main synclinal structures (defined by a blue color) were delineated using the low pass [82] (Figure 6) and UPWC (Figure 7) [78] filters, which roughly overlap with the zones of Obubra (southern), Uburu (southwest) and Okpoma (northeast) areas that fall under the Ikom-Mamfe Rift, Afikpo and Ogoja Synclines, respectively [58,94]. These structures sandwiched the main Santonian [93] and Tertiary-Recent [63] tectonic intrusions (red-pink color) of the AA and IMR, respectively. Some geophysical studies have reported the coexistence of intrusions and troughs in the BT [74,95]. The OP eastern part, which is dominated by magnetite, is characterized by intrusions and outcrops of igneous basements [9]. 


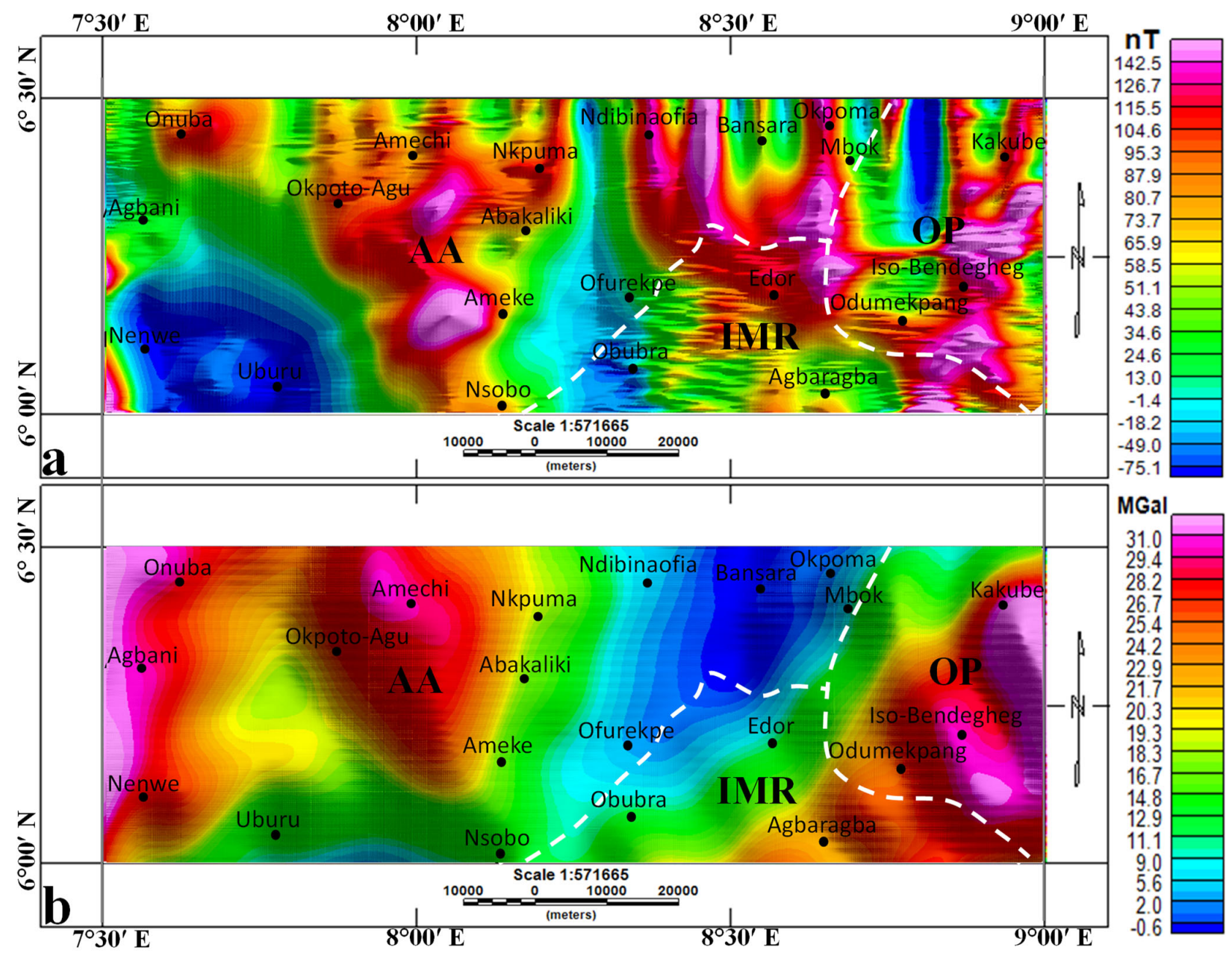

Figure 6. Low pass maps of (a) total magnetic intensity and (b) Bouguer gravity data. AA: Abakaliki Anticlinorium, OP: Obudu Plateau, IMR: Ikom-Mamfe Rift.

To view the lithologic units of the underlying basement based on their susceptibilities and densities, the high susceptibility (0.00057 in cgs units) and density $(2.91 \mathrm{~g} / \mathrm{cc})$ values are due to basic rocks, whereas lower susceptibility (0.0003 in cgs units) and density ( $2.81 \mathrm{~g} / \mathrm{cc})$ values are due to acidic rocks. The models (Figures 8 and 9) reveal that the Cretaceous deposits are severely fractured, folded, and baked [26,57]. Again, normal fault blocks associated with the intrusions were delineated by the models. Profile 1 (Figure 8 ) that cuts across part of AA and ends at OP (Figure 4) is characterized by two prominent igneous intrusions related to the Santonian AA [58,93]. The location of the igneous intrusion at the western end of profile 2 (Figure 9) seems to match closely with the position of the intrusion in Figure 8. This indicates the elongated nature of the anticlinal structure of the AA that trends in the N-S direction (Figures 6 and 7). Towards the eastern part of profile 2 (Figure 9), the intrusion is outcropped in Agbaragba. Within this area and neighborhood, there are several reported extrusive rocks such as syenites, basalts, and trachytes [96,97] related to the CVL [63]. Because of the proliferation of intrusions [93] and basement rocks in outcrop sections in the OP $[68,98]$, the investigated area is characterized by depths generally $<3000 \mathrm{~m}$. This depth estimate coincides relatively well with previous findings in the area $[27,31,32,35,37]$. 


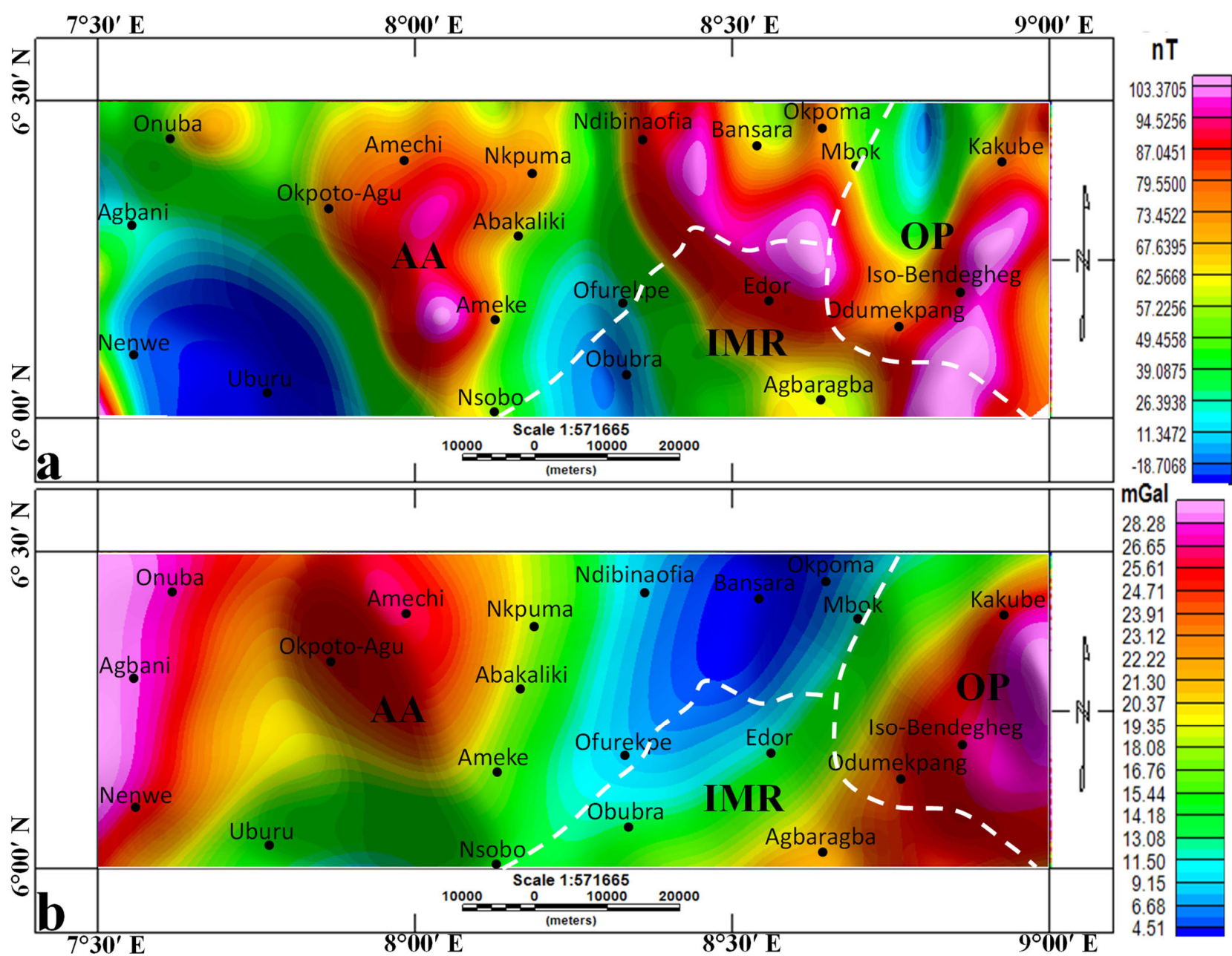

Figure 7. Upward, continued to $3000 \mathrm{~m}$, maps of (a) total magnetic intensity and (b) Bouguer gravity data. AA: Abakaliki Anticlinorium, OP: Obudu Plateau, IMR: Ikom-Mamfe Rift.

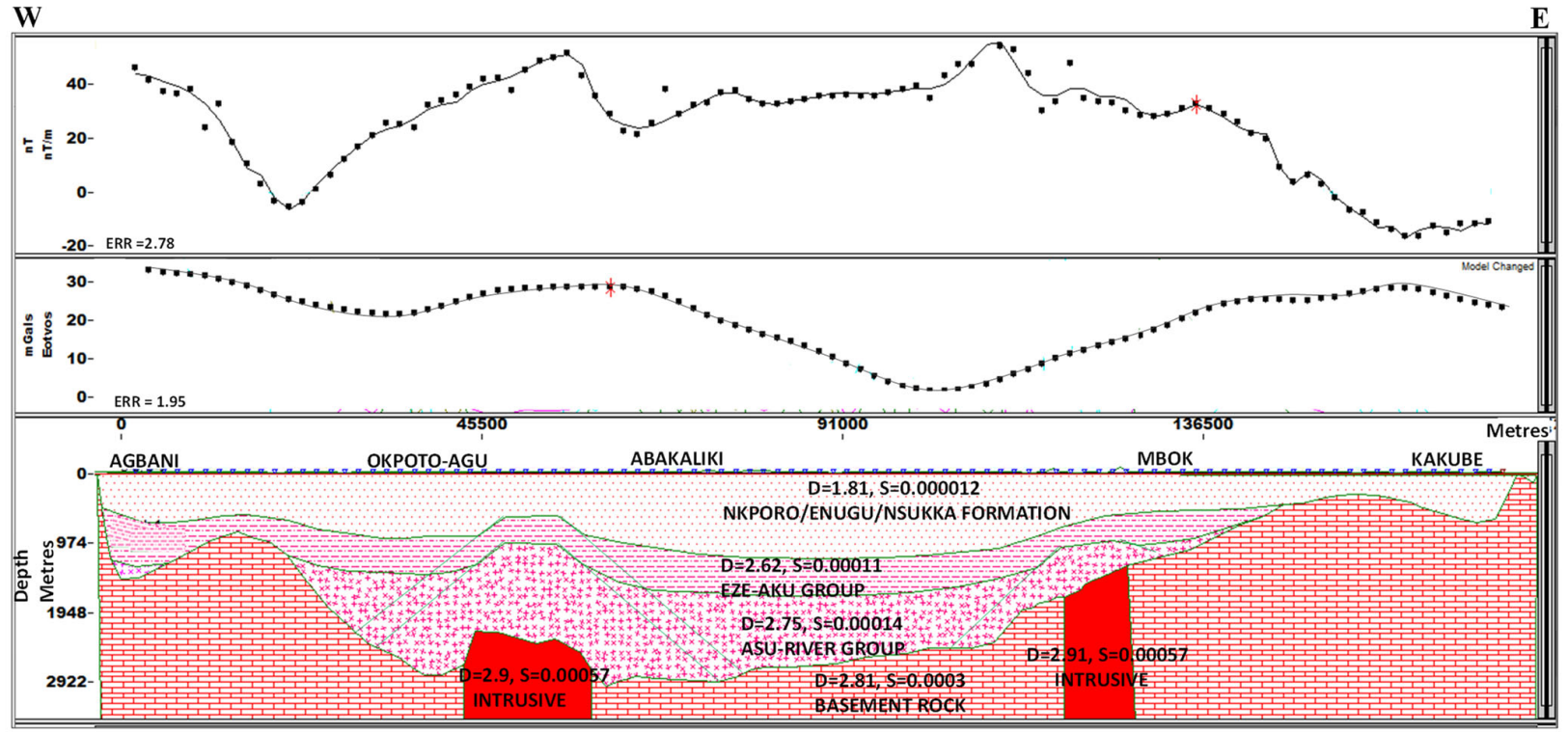

Figure 8. 2D joint magnetic and gravity model obtained from profile 1. 


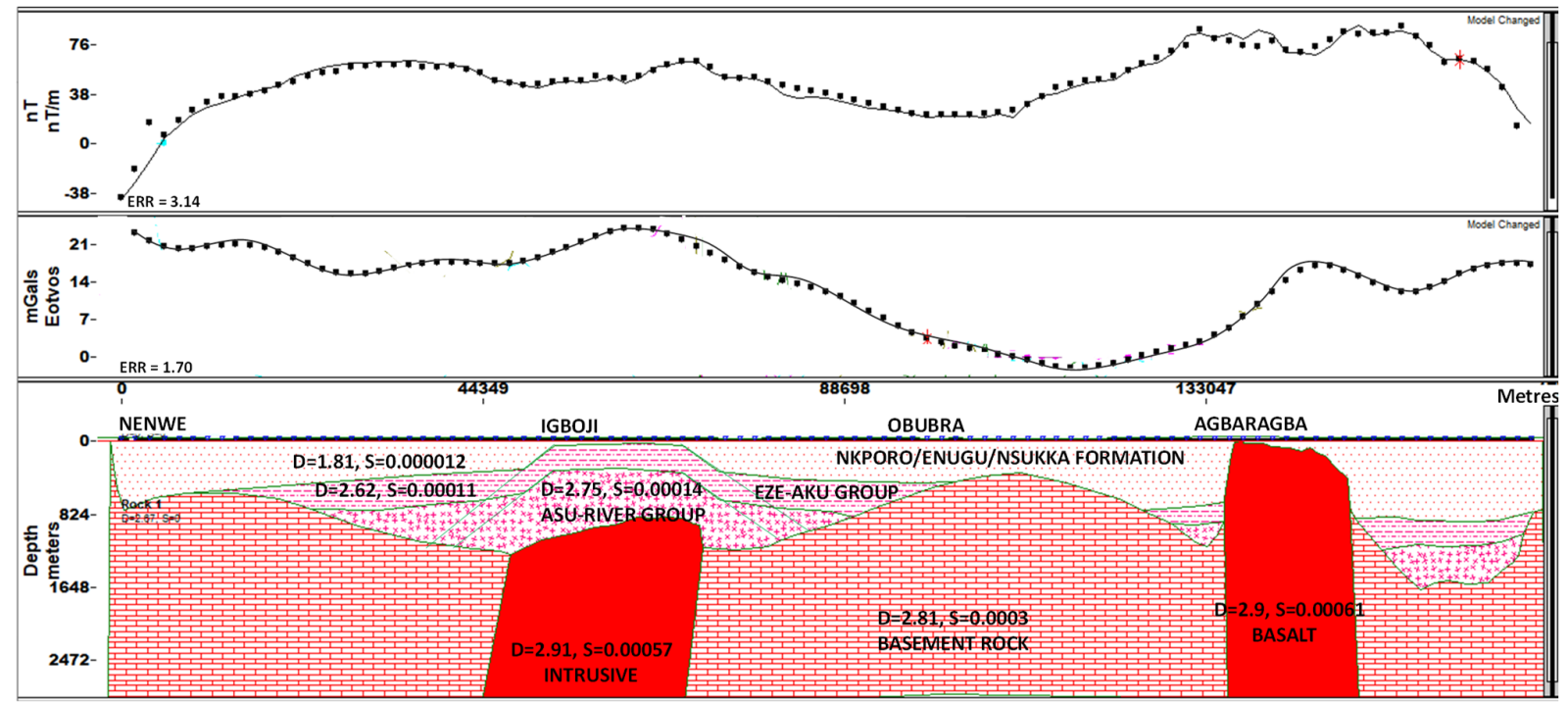

Figure 9. 2D joint magnetic and gravity model obtained from profile 2.

\section{Discussion of Results}

The LBT is relatively well known because of geoscience investigations for natural resources. Hydrocarbon, lead, zinc, barite, and brine are commonly explored in southeast Nigeria $[3,63,93]$. The occurrence of brines and genesis in the LBT have been investigated by several geoscientists $[1,3,4,15-17,65,66,99]$ with contrasting reports. In $[17,65,66]$, the authors stated from their various geophysical studies that brine fields are characterized by multi-layered saline zones in the subsurface. In [4,15], the authors suggested that these brines are products of the dissolution of halite and palaeo/fossil seawater. In [16], the authors also opined marine rather than a continental source for these brines. While [1] suggested evaporite minerals and chalcophile element sources, Ref. [3] suggested that brines originated from connate water.

Modern investigations by [10,20-25,100-103] connected the origin of brines in a rift environment, such as LBT, to igneous intrusions. Previously, sodium chloride and hydrochloride acid were detected by [104] in the emanations of volcanoes. In addition, Refs. [105,106] discussed the volcanic origin of salt. In $[3,26,100]$, the authors reported the occurrence of brine in the neighborhood of igneous intrusions in the BT. Figures 6 and 7 indicated the locations of the Afikpo syncline (Uburu and the surrounding area), Obubra (in the c), and the Ogoja syncline (Okpoma and the adjoining region), represented by a blue color. These areas are depocenters bordering intrusions (represented by red-pink color) associated with the Santonian AA [74] and Tertiary-Recent intrusions of the IMR [7]. These synclinal structures, that are dominated by argillite, coincide with the sites of the major brine fields in the investigation area $[1,4,16,17,66,99]$. Intrusions delineated by Figures 8 and 9 occur in the neighborhood of the brine fields. This finding validates the results of Figures 7 and 8 . Igneous intrusion systems in rifted basins are usually distinguished by networks of interrelated, laterally, and vertically wide-ranging complexes of dykes and sills that transgress basin stratigraphy [42]. These intrusions are associated with normal fault blocks, faults, uplifts, and folds. The faults and other openings serve as a pathway for the hydrothermal fluid's migration upward. The widespread occurrence of igneous intrusions in the investigated area signifies a critical geological risk in hydrocarbon surveys [101].

Furthermore, intrusions are commonly connected to hydrothermal fluid [21,40,100] that is as salty or even saltier than seawater, and may have some traces of dissolved minerals such as lead, zinc, copper, and gold. In the LBT, there are massive occurrences of lead-zinc-barite coexistence with salt ponds $[3,28,31]$. The presence of salt in the water halts the metallic minerals from precipitating out of the brine, as the chlorides in the salt preferentially bond with the metals $[22,100]$. Nevertheless, since the brine is hot, the 
minerals dissolve more easily [40]. As magma cools, it frees its super-heated, mineralenriched water (metalliferous brines) into adjoining rock [21,40]. As they travel long distances laterally, they experience modifications in pressure and/or composition [100]. The hydrothermal fluid becomes diluted once they come into contact with meteoric water (groundwater). Fluid flow in the fractured upper crust is usually driven by hydraulic gradients, which may perhaps result from a number of different possible causes and imbalances, including thermal and chemical disequilibrium, topography, overburden loads [100], and attendant convective cells in the hydrothermal system. They drive the brines up through hydraulic boundary faults / fractures via porous and permeable strata until oozing takes place at the surface (Figure 10). This conceptual model was created based on the geologic, stratigraphic (Figure 3) and tectonic history of the study area. Additionally, geodynamic information on the robust thermally driven convection process [105], related heat, and movement of hydrothermal fluid [22], served as a control in the design of the model. The metals are precipitated out when the brines rise and cool [22]. The cool brines are then trapped by argillite close to the Earth's surface and occur as salt ponds such as those present at Uburu, Okposi, Okpoma, etc. in the studied area. The absence of hot springs in the studied area may be due to a lack of deep-reaching vertical circulation systems $[107,108]$.

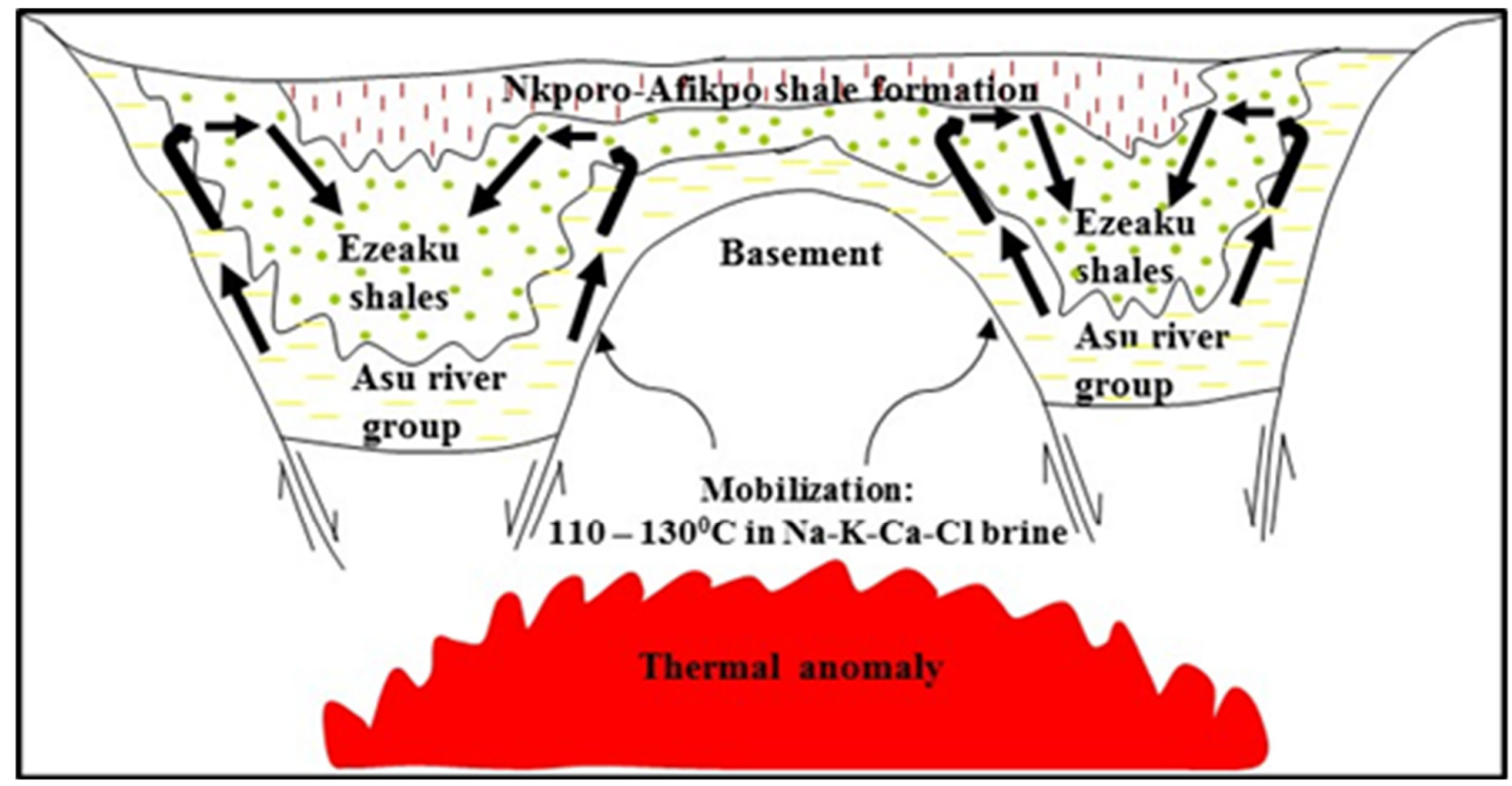

Figure 10. Conceptual model of brine source in the Lower Benue Trough.

Moreover, ascent channels for hydrothermal fluids are very conducting structures allowing high flow rates so that hot brines can reach the surface environment at high temperatures [108]. The conceptual model (Figure 10) of the hydrothermal system of the LBT agrees with the Darcy flow law [109], describing fluid flow through porous media. This defines the ability of a fluid to flow through a porous media such as rock. It relies on the fact that the amount of flow between two points is directly related to the difference in pressure between the points, the distance between the points, and the interconnectivity of flow pathways in the rock between the points. The measurement of interconnectivity is called permeability.

The Darcy law is expressed as:

$$
\vec{q}=-[K] \frac{1}{g} \nabla P
$$


where, $\vec{q}$ is the specific discharge vector per cross sectional area $\left(\mathrm{m}^{3} \mathrm{~s}^{-1} \mathrm{~m}^{-2}\right)$ with the components $q_{x}, q_{z}, q_{z},(\mathrm{~K})\left(\mathrm{m} \mathrm{s}^{-1}\right)$ the tensor of hydraulic conductivity, $\mathrm{K}\left(\mathrm{kg} \mathrm{m}^{-3}\right)$ the density of the fluid, $g\left(\mathrm{~m} \mathrm{~s}^{-2}\right)$ the acceleration due to gravity, and $\nabla P\left(\mathrm{~kg} \mathrm{~m}^{-2} \mathrm{~s}^{-2}\right.$ or $\mathrm{Pa} \mathrm{m}^{-1}$ ) the vector of the pressure gradient.

\section{Conclusions}

Investigation connecting igneous intrusions and associated hydrothermal fluids as a brine source in a rifted environment such as BT was carried out in southeastern Nigeria. To map these intrusions and determine their spatial distributions within the study area, HRPF data were used. The ASig results showed the spatial distribution of the short- and long-wavelength geologic structures. The main igneous bodies and bordering synclines, which coincide with the sites of Uburu, Obubra, and Okpoma salt ponds, were delineated by the low pass, UPWC, and 2D GM-SYS results. In general, the low-frequency maps and 2D models showed brine field sites in the neighborhood of magnetic intrusions, which are commonly associated with metalliferous brines. To fit these interpretations into the overall stratigraphic and geologic settings of the area, a conceptual model of the brine source was generated. This model is more akin to a hydrothermal system that is driven by associated convective cells of the hydrothermal fluid and overburden loads. Furthermore, studies involving geochemical analyses of the brines and adjoining igneous rocks should be carried out to compare their elemental composition, which will be the subject of future research.

Author Contributions: Conceptualization, A.M.E.; Data curation, S.E.E.; Formal analysis, O.-I.M.A.; Funding acquisition, K.A. Investigation, A.E.A., C.E.T. and P.A.; Methodology, S.E.E.; Supervision, A.M.E.; Validation, O.-I.M.A.; Writing-original draft, A.E.A., O.-I.M.A., C.E.T. and K.A.; Writing-review \& editing, A.M.E. All authors have read and agreed to the published version of the manuscript.

Funding: This research was funded by Researchers Supporting Project number (RSP-2022/351), King Saud University, Riyadh, Saudi Arabia.

Acknowledgments: Deep thanks and gratitude to the Researchers Supporting Project number (RSP2022/351), King Saud University, Riyadh, Saudi Arabia for funding this research article.

Conflicts of Interest: The authors declare no conflict of interest.

\section{References}

1. Eseme, E.; Agyingi, C.M.; Foba-Tendo, J. Geochemistry and genesis of brine emanations from Cretaceous strata of the Mamfe Basin, Cameroon. J. Afr. Earth Sci. 2002, 35, 467-476. [CrossRef]

2. Toteu, S.F.; Penaye, J.; Djomani, Y.P. Geodynamic evolution of the Pan-African belt in Central Africa with special reference to Cameroon. Can. J. Earth Sci. 2004, 41, 73-85. [CrossRef]

3. Uma, K.O. The brine fields of the Benue Trough, Nigeria: A comparative study of geomorphic, tectonic and hydrochemical properties. J. Afr. Earth Sci. 1998, 26, 261-275. [CrossRef]

4. Tijani, M.N. Evolution of saline waters and brines in the Benue-Trough, Nigeria. Appl. Geochem. 2004, 19, 1355-1365. [CrossRef]

5. Offodile, M.E. The geology of the Middle Benue, Nigeria. Ph.D. Thesis, University of Upsala, Uppsala, Sweden, 1976; 166p.

6. Tattam, C.H. Preliminary report on the salt industry in Nigena. Geol. Surv. Niger. Rep. 1943, 778.

7. Uzuakpunwa, A.B. The geochemistry and origin of the evaporite deposits in the southern half of the Benue Trough. Earth Evol. Sci. 1981, 2, 136-139.

8. Egboka, B.C.E.; Uma, K.O. Hydrochemistry, contaminant transport and their tectonic effects in the Okposi-Uburu salt lake area, Imo State, Nigeria. Hydrol. Sci. J. 1986, 31, 205-221. [CrossRef]

9. Ford, S.O. The economic mrneral resources of the Benue Trough. Earth Evol. Sci. 1980, 1, 154-163.

10. Orajaka, S.O. Salt water resources of East Central State of Nigeria. J. Min. Geol. 1972, 7, 35-41.

11. Akande, S.O.; Horn, E.E.; Reutel, C. Mineralogy, fluid inclusion and genesis of the Arufu and Akwana Pb-Zn-F mineralizabon, Middle Benue Trough, Nigeria. J. Afr. Earth Sci. 1988, 7, 167-180. [CrossRef]

12. Farrington, I.L. A preliminary description of the Nigerian Lead-Zinc field. Econ. Geol. 1952, 7, 483-608. [CrossRef]

13. McConnel, R.B. Notes on the Lead-Zinc deposits of Nigeria and Cretaceous stratigraphy of the Benue and Cross River Valleys. Geological Survey of Nigeria Report. No. 752. Niger. Geol. Surv. Rep. 1949; unpublished.

14. Olade, M.A. Evolution of Nrgeria's Benue Trough of Nigeria (aulacogen): A tectonic model. Geol. Mag. 1975, 112, 575-583. [CrossRef] 
15. Tijani, M.N.; Loehnert, E.P.; Uma, K.O. Origin of saline groundwaters in the Ogoja area, Lower Benue Trough, Nigeria. J. Afr. Earth Sci. 1996, 23, 237-252. [CrossRef]

16. Ushie, F.; Eminue, O.; Nwankwoala, H. Occurrence of Brines $(\mathrm{NaCl})$ and their effect on the Groundwater of Okpoma and Environs, Southeastern Nigeria. Int. J. Adv. Sci. Tech. Res. 2014, 4, 2249-9954.

17. Umar, N.D.; Idris, I.G.; Abdullahi, A.I. Hydrogeophysical investigation of the aquifers of brine field of awe and environs, Central Benue Trough, Nigeria. Int. J. Sci. Eng. Res. 2018, 9, 1852-1868.

18. Fan, Q.; Ma, H.; Lai, Z.; Tan, H.; Li, T. Origin and evolution of oilfield brines from Tertiary strata in western Qaidam Basin: Constraints from $87 \mathrm{Sr} / 86 \mathrm{Sr}, \delta \mathrm{D}, \delta 18 \mathrm{O}, \delta 34 \mathrm{~S}$ and water chemistry. Chin. J. Geochem. 2010, 29, 446-454. [CrossRef]

19. Xun, Z.; Cijun, L.; Xiumin, J.; Qiang, D.; Lihong, T. Origin of subsurface brines in the Sichuan basin. Ground Water 1996, 35, 53-58. [CrossRef]

20. Blundy, J.; Mavrogenes, J.; Tattitch, B.; Sparks, S.; Gilmer, A. Generation of porphyry copper deposits by gas-brine reaction in volcanic arcs. Nat. Geosci. 2015, 8, 235-240. [CrossRef]

21. Dill, H.G.; Botz, R.; Berner, Z.; Hamad, A.B.A. The origin of pre- and synrift, hypogene Fe-P mineralization during the Cenozoic along the Dead Sea Transform Fault, Northwest Jordan. Econ. Geol. 2010, 105, 1301-1319. [CrossRef]

22. Mineral Resources of the Western US. The Teacher-Friendly Guide to the Earth Scientist of the Western US. 2017. Available online: http:/ /geology.Teacherfriendlyguide.Org/index.php/mineral-w (accessed on 1 December 2021).

23. Risacher, F.; Alonsob, H.; Salazar, C. The origin of brines and salts in Chilean salars: A hydrochemical review. Earth-Sci. Rev. 2003, 63, 249-293. [CrossRef]

24. Sharma, R.; Srivastava, P.K. Hydrothermal fluids of magmatic origin. In Modelling of Magmatic and Allied Processes; Society of Earth Scientists Series; Springer: Berling/Heidelberg, Germany, 2014. [CrossRef]

25. Xu, K.; Yu, B.; Gong, H.; Ruan, Z.; Pan, Y.; Ren, Y. Carbonate reservoirs modified by magmatic intrusions in the Bachu area, Tarim Basin, NW China. Geosci. Front. 2015, 6, 779-790. [CrossRef]

26. Ekwok, S.E.; Akpan AEKudamnya, E.A.; Ebong, D.E. Assessment of groundwater potential using geophysical data: A case study in parts of Cross River State, south-eastern Nigeria. Appl. Water Sci. 2020, 10, 144. [CrossRef]

27. Ekwok, S.E.; Akpan, A.E.; Ebong, D.E. Enhancement and modelling of aeromagnetic data of some inland basins, southeastern Nigeria. J. Afr. Earth Sci. 2019, 155, 43-53. [CrossRef]

28. Akande, S.O.; Muecke, A. Co-existing copper sulphides and sulphosalts in the Abakaliki Pb-Zn deposits, lower Benue-Trough (Nigeria) and their genetic significance. Miner. Pet. 1993, 47, 183-192. [CrossRef]

29. Nwachukwu, S.O. The tectonic evolution of the southern portion of the Benue Trough, Nigeria. Geol. Mag. 1972, 109, 411-419. [CrossRef]

30. Olade, M.A.; Morton, R.D. Origin of lead-zinc mineralization in the southern Benue-Trough, Nigeria: Fluid inclusion and trace element studies. Mineral. Dep. 1985, 20, 76-80. [CrossRef]

31. Ekwok, S.E.; Akpan, A.E.; Kudamnya, E.A. Exploratory mapping of structures controlling mineralization in Southeast Nigeria using high resolution airborne magnetic data. J. Afr. Earth Sci. 2020, 162, 103700. [CrossRef]

32. Ekwok, S.E.; Akpan, A.E.; Achadu, O.I.M.; Eze, O.E. Structural and lithological interpretation of aero-geophysical data in parts of the Lower Benue Trough and Obudu Plateau, Southeast Nigeria. Adv. Space Res. 2021, 68, 2841-2854. [CrossRef]

33. Ekinci, Y.L.; Balkaya, Ç.; Göktürkler, G. Parameter estimations from gravity and magnetic anomalies due to deep-seated faults: Differential evolution versus particle swarm optimization. Turk. J. Earth Sci. 2019, 28, 860-881.

34. Mehanee, S. A new scheme for gravity data interpretation by a faulted 2-D horizontal thin block: Theory, numerical examples and real data investigation. In IEEE Transactions on Geoscience and Remote Sensing; IEEE: Piscataway, NJ, USA, 2022. [CrossRef]

35. Ekwok, S.E.; Akpan, A.E.; Ebong, E.D. Assessment of crustal structures by gravity and magnetic methods in the Calabar Flank and adjoining areas of Southeastern Nigeria-a case study. Arab. J. Geosci. 2021, 14, 1-10. [CrossRef]

36. Ekinci, Y.L.; Balkaya, Ç.; Göktürkler, G.; Özyalın, Ş. Gravity data inversion for the basement relief delineation through global optimization: A case study from the Aegean Graben System, western Anatolia, Turkey. Geophys. J. Int. 2021, 224, 923-944. [CrossRef]

37. Ekwok, S.E.; Akpan, A.E.; Achadu, O.I.M.; Ulem, C.A. Implications of tectonic anomalies from potential feld data in some parts of Southeast Nigeria. Environ. Earth Sci. 2022, 81, 6. [CrossRef]

38. Balkaya, Ç.; Ekinci, Y.L.; Göktürkler, G.; Turan, S. 3D non-linear inversion of magnetic anomalies caused by prismatic bodies using differential evolution algorithm. J. Appl. Geophys. 2017, 136, 372-386. [CrossRef]

39. Balkaya, Ç.; Göktürkler, G.; Erhan, Z.; Ekinci, Y.L. Exploration for a cave by magnetic and electrical resistivity surveys: Ayvacık Sinkhole example, Bozdağ, İzmir (western Turkey). Geophysics 2012, 77, 135-146. [CrossRef]

40. United States Geological Survey (USGS). Setting and Origin of Iron Oxide-Copper-Cobalt-Gold-Rare Earth Element Deposits of Southeast Missouri. 2013. Available online: http://minerals.usgs.gov/east/semissouri/index.html (accessed on 23 January 2022).

41. Telford, W.M.; Geldart, L.P.; Sheriff, R.E. Applied Geophysics, 2nd ed.; Cambridge University Press: Cambridge, UK, 1990.

42. Eldosouky, A.M.; Sehsah, H.; Elkhateeb, S.O.; Pour, A.B. Integrating aeromagnetic data and Landsat-8 imagery for detection of post-accretionary shear zones controlling hydrothermal alterations: The Allaqi-Heiani Suture zone, South Eastern Desert, Egypt. Adv. Space Res. 2020, 65, 1008-1024. [CrossRef] 
43. Eldosouky, A.M.; Elkhateeb, S.O. Texture analysis of aeromagnetic data for enhancing geologic features using co-occurrence matrices in Elallaqi area, South Eastern Desert of Egypt. NRIAG J. Astron. Geophys. 2018, 7, 155-161. [CrossRef]

44. Eldosouky, A.M.; Abdelkareem, M.; Elkhateeb, S.O. Integration of remote sensing and aeromagnetic data for mapping structural features and hydrothermal alteration zones in Wadi Allaqi area, South Eastern Desert of Egypt. J. Afr. Earth Sci. 2017, 130, 28-37. [CrossRef]

45. Eldosouky, A.M.; Mohamed, H. Edge detection of aeromagnetic data as effective tools for structural imaging at Shilman area, South Eastern Desert, Egypt. Arab. J. Geosci. 2021, 14, 13. [CrossRef]

46. Elkhateeb, S.O.; Eldosouky, A.M.; Khalifa, M.O.; Aboalhassan, M. Probability of mineral occurrence in the Southeast of Aswan area, Egypt, from the analysis of aeromagnetic data. Arab. J. Geosci. 2021, 14, 1514. [CrossRef]

47. Pham, L.T.; Eldosouky, A.M.; Melouah, O.; Abdelrahman, K.; Alzahrani, H.; Oliveira, S.P.; Andráš, P. Mapping subsurface structural lineaments using the edge filters of gravity data. J. King Saud Univ.-Sci. 2021, 33, 101594. [CrossRef]

48. Pham, L.T.; Nguyen, D.A.; Eldosouky, A.M.; Abdelrahman, K.; Vu, T.V.; Al-Otaibi, N.; Ibrahim, E.; Kharbish, S. Subsurface structural mapping from high-resolution gravity data using advanced processing methods. J. King Saud Univ. Sci. 2021, $33,101488$. [CrossRef]

49. Pham, L.T.; Oksum, E.; Do, T.D.; Nguyen, D.V.; Eldosouky, A.M. On the performance of phase-based filters for enhancing lateral boundaries of magnetic and gravity sources: A case study of the Seattle uplift. Arab. J. Geosci. 2021, 14, 129. [CrossRef]

50. Pham, L.T.; Eldosouky, A.M.; Oksum, E.; Saada, S.A. A new high resolution filter for source edge detection of potential data. Geocarto Int. 2020, 1-18. [CrossRef]

51. Saada, A.S.; Eldosouky, A.M.; Kamal, A.; Al-Otaibi, N.; Ibrahim, E.; Ibrahim, A. New insights into the contribution of gravity data for mapping the lithospheric architecture. J. King Saud Univ.-Sci. 2021, 33, 101400. [CrossRef]

52. Saada, A.S.; Mickus, K.; Eldosouky, A.M.; Ibrahim, A. Insights on the tectonic styles of the Red Sea rift using gravity and magnetic data. Mar. Pet. Geol. 2021, 133, 105253. [CrossRef]

53. Sehsah, H.; Eldosouky, A.M. Neoproterozoic hybrid forearc-MOR ophiolite belts in the northern Arabian-Nubian Shield: No evidence for back-arc tectonic setting. Int. Geol. Rev. 2020, 1-13. [CrossRef]

54. Elkhateeb, S.O.; Eldosouky, A.M. Detection of porphyry intrusions using analytic signal (AS), Euler Deconvolution, and Centre for Exploration Targeting (CET) Technique Porphyry Analysis at Wadi Allaqi Area, South Eastern Desert, Egypt. Int. J. Eng. Res. 2016, 7, 471-477.

55. Essa, K.S.; Mehanee, S.; Soliman, K.; Diab, Z.E. Gravity profile interpretation using the R-parameter imaging technique with application to ore exploration. Ore Geol. Rev. 2020, 126, 103695. [CrossRef]

56. Kearey, P.; Brooks, M.; Hill, I. An Introduction to Geophysical Exploration, 3rd ed.; Blackwell Science Ltd Editorial Offices: New York, NY, USA, 2002.

57. Abu El-Magd, S.A.; Eldosouky, A.M. An improved approach for predicting the groundwater potentiality in the low desert lands; El-Marashda area, Northwest Qena City, Egypt. J. Afr. Earth Sci. 2021, 179, 104200. [CrossRef]

58. Ekwok, S.E.; Akpan, A.E.; Ebong, E.D.; Eze, O.E. Assessment of depth to magnetic sources using high resolution aeromagnetic data of some parts of the Lower Benue Trough and adjoining areas, Southeast Nigeria. Adv. Space Res. 2021, 67, 2104-2119. [CrossRef]

59. Mehanee, S. Simultaneous joint inversion of residual gravity and self-potential data measured along profile: Theory, numerical examples and a case study from mineral exploration with cross validation from electromagnetic data. IEEE Trans. Geosci. Remote Sens. 2022, 60, 1-20. [CrossRef]

60. Cherkashov, G.; Poroshina, I.; Stepanova, T.; Ivanov, V.; Bel'tenev, V.; Lazareva, L.; Rozhdestvenskaya, I.; Samovarov, M.; Shilov, V.; Glasby, G.P.; et al. Seafloor Massive Sulfides from the Northern Equatorial Mid-Atlantic Ridge: New Discoveries and Perspectives. Mar. Georesources Geotechnol. 2010, 28, 222-239. [CrossRef]

61. Gunn, P.J.; Dentith, M.C. Magnetic responses associated with mineral deposits. AGSO J. Aust. Geol. Geophys. 1997, 17, 145-158.

62. Correia, A.; Jones, F.W. On the existence of a geothermal anomaly in southern Portugal. Tectonophysics 1997, 271, 123-134. [CrossRef]

63. Akpan, A.E.; Ebong, D.E.; Ekwok, S.E.; Joseph, S. Geophysical and Geological Studies of the Spread and Industrial Quality of Okurike Barite Deposit. Am. J. Environ. Sci. 2014, 10, 566-574. [CrossRef]

64. Mbah, V.O.; Onwuemesi, A.G.; Aniwetalu, E.U. Exploration of lead-zinc (Pb-Zn) mineralization using very low frequency electromanetic (VLF-EM) in Ishiagu, Ebonyi State. J. Geol. Geophys. 2015, 4, 1-7.

65. Mbipom, E.W.; Okon-Umoren, O.E.; Umoh, J.U. Geophysical investigations of salt ponds in Okpoma area south-eastern Nigeria. J. Min. Geol. Niger. 1990, 26, 285-290.

66. Okoyeh, E.I.; Akpan, A.E.; Egboka, B.C.E.; Okolo, M.C.; Okeke, H.C. Geophysical delineation of subsurface fracture associated with Okposi-Uburu Salt Lake Southeastern, Nigeria. Int. Res. J. Environ. Sci. 2015, 4, 1-6.

67. Ugbor, D.O.; Okeke, F.N. Geophysical investigation in the Lower Benue trough of Nigeria using gravity method. Int. J. Phys. Sci. 2010, 5, 1757-1769.

68. Agbi, I.; Ekwueme, B.N. Preliminary review of the geology of the hornblende biotite gneisses of Obudu Plateau Southeastern Nigeria. Glob. J. Geol. Sci. 2018, 17, 75-83. [CrossRef]

69. Dada, S.S. Crust-forming ages and Proterozoic crustal evolution in Nigeria: A reappraisal of current interpretations. Precambrian Res. 1998, 87, 65-74. [CrossRef] 
70. Ukwang, E.E.; Ekwueme, B.N.; Kröner, A. Single zircon evaporation ages: Evidence for the Mesoproterozoic crust in S.E. Nigerian basement complex. Chin. J. Geochem. 2012, 31, 48-54. [CrossRef]

71. Haruna, I.V. Review of the Basement Geology and Mineral Belts of Nigeria. J. Appl. Geol. Geophys. 2017, 5, 37-45.

72. Fairhead, J.D.; Okereke, C.S.; Nnange, J.M. Crustal Structure of the Mamfe basin, West Africa, based on gravity data. Tectonophysics 1991, 186, 351-358. [CrossRef]

73. Dumort, J.C. Carte Géologique de Reconnaissance et Note Explicative sur la Feuille Douala-Ouest (1:500000); Direction des Mines et de la Géologie du Cameroun: Yaoundé, Cameroun, 1968.

74. Ofoegbu, C.O.; Onuoha, K.M. Analysis of magnetic data over the Abakaliki Anticlinorium of the Lower Benue Trough, Nigeria. Mar. Pet. Geol. 1991, 8, 174-183. [CrossRef]

75. Reyment, R.A. Aspects of the Geology of Nigeria; Ibadan University Press: Ibadan, Nigeria, 1965.

76. Benkhelil, J. Structure et evolution geodynamique du Basin intracontinental de la Benoue (Nigeria). Bull. Cent. Rech. Explor. Prod. Elf-Aquitaine 1988, 12, 29-128.

77. Milligan, P.; Gunn, P. Enhancement and presentation of airborne geophysical data. AGSO J. Aust. Geol. Geophys. 1997, 17, 63-75.

78. Roest, W.R.; Verhoef, J.; Pilkington, M. Magnetic interpretation using the 3-D analytic signal. Geophysics 1992, 57, 116-125. [CrossRef]

79. Essa, K.S.; Mehanee, S.; Elhussein, M. Magnetic data profiles interpretation for mineralized buried structures identification applying the variance analysis method. Pure Appl. Geophys. 2020, 178, 973-993. [CrossRef]

80. Klingele, E.E.; Marson, I.; Kahle, H.G. Automatic interpretation of gravity gradiometric data in two dimensions: Vertical gradients. Geophys. Prospect. 1991, 39, 407-434. [CrossRef]

81. Mehanee, S.; Essa, K.S.; Diab, Z.E. Magnetic data interpretation using a new R-parameter imaging method with application to mineral exploration. Nat. Resour. Res. 2020, 30, 77-95. [CrossRef]

82. Fraser, D.C.; Fuller, B.D.; Ward, S.H. Some numerical techniques for application in mining exploration. Geophysics 1966, 31, 1066-1077. [CrossRef]

83. Nabighian, M.N. The analytical signal of two dimensional magnetic bodies with polygon cross-section: Its properties and use for automated anomaly interpretation. Geophysics 1972, 37, 507-517. [CrossRef]

84. Nabighian, M.N. Towards the three-dimensional automatic interpretation of potential field data via generalized Hilbert transforms: Fundamental relations. Geophysics 1984, 53, 957-966. [CrossRef]

85. Zahra, H.S.; Oweis, H.T. Application of high-pass filtering techniques on gravity and magnetic data of the eastern Qattara Depression area, Western Desert, Egypt. NRIAG J. Astron. Geophys. 2016, 5, 106-123. [CrossRef]

86. Allen, R.L.; Mills, D.W. Signal Analysis, Time, Frequency, Scale, and Structure; IEEE Press: Piscataway, NJ, USA, 2004.

87. Reeves, C.; Reford, S.; Millingan, P. Airborne geophysics: Old methods, new images. In Proceedings of the Fourth Decennial. International Conference on Mineral Exploration; Gubins, A., Ed.; Prospectors and Developers Association of Canada: Toronto, ON, Canada, 1997; pp. 13-30.

88. Talwani, M.; Hiertzler, J.R. Computation of magnetic anomalies caused by two dimensional bodes of arbitrary shape. Geol. Sci. 1964, 9, 464-480.

89. Talwani, M.; Worzel, J.L.; Landisman, M. Rapid gravity computations for 2 dimensional bodies with application to the Mendocino submarine fracture zone. J. Geophys. Res. 1959, 64, 49-59. [CrossRef]

90. Won, I.J.; Bevis, M. Computing the gravitational and magnetic anomalies due to a polygon: Algorithms and Fortran subroutines. Geophysics 1987, 52, 232-238. [CrossRef]

91. Essa, K.S.; Elhussein, M. A new approach for the interpretation of magnetic data by a 2-D dipping dike. J. Appl. Geophys. 2017, 136, 431-443. [CrossRef]

92. Essa, K.S.; Elhussein, M. PSO (particle swarm optimization) for interpretation of magnetic anomalies caused by simple geometrical structures. Pure Appl. Geophys. 2018, 175, 3539-3553. [CrossRef]

93. Benkhelil, J. Cretaceous deformation, magmatism, and metamorphism in the Lower Benue Trough, Nigeria. Geol. J. 1987, 22, 467-493. [CrossRef]

94. Kogbe, C.A. Geology of Nigeria: A Review; Elizabethan Publishing Co.: Lagos, Nigeria, 1976; pp. 436-468.

95. Ofoegbu, C.O.; Mohan, N.L. Interpretation of aeromagnetic anomalies over part of southeastern Nigeria using three-dimensional Hilbert transformation. Pure Appl. Geophys. 1990, 134, 13-29. [CrossRef]

96. Abolo, M.G. Geology and petroleum potential of the Mamfe basin, Cameroon, central Africa. Afr. Geosci. Rev. 2008, $12,65-77$.

97. Ajonina, H.N.; Ajibola, O.A.; Bassey, C.E. The Mamfe Basin, SE Nigeria and SW Cameroon: A review of the basin filling model and tectonic evolution. J. Geosci. Soc. Cameroon 2002, 1, 24-25.

98. Arinze, J.I.; Emedo, O.C.; Ngwaka, A.C. Analysis of aeromagnetic anomalies and structural lineaments for mineral and hydrocarbon exploration in Ikom and its environs southeastern Nigeria. J. Afr. Earth Sci. 2019, 151, 274-285.

99. Lar, U.A.; Sallau, A.K. Trace element geochemistry of the Keana brines field, Middle Benue Trough. Environ. Geochem. Health 2005, 27, 331-339. [CrossRef]

100. Barton, M.D.; Johnson, D.A. Alternative brine sources for Fe-Oxide (-Cu-Au) systems: Implications for hydrothermal alteration and metals. In Hydrothermal Iron Oxide Copper-Gold E Related Deposits: A Global Perspective; Porter, T.M., Ed.; Australian Mineral Foundation: Adelaide, Australia, 2000; pp. 43-60. 
101. Holford, S.P.; Schofield, N.; Jackson, C.A.L.; Magee, C.; Green, P.F.; Duddy, I.R. Impacts of igneous intrusions on source and reservoir potential in prospective sedimentary basins along the Western Australian continental margin. In Proceedings of the West Australian Basins Symposium, Perth, WA, Australia, 18-21 August 2013; pp. 1-12.

102. Neupane, G.; Wendt, D.S. Assessment of Mineral Resources in Geothermal Brines in the US. In Proceedings of the 42nd Workshop on Geothermal Reservoir Engineering, Stanford, CA, USA, 13-15 February 2017; pp. 1-18.

103. Vehling, F.; Hasenclever, J.; Rüpke, L. Brine formation and mobilization in submarine hydrothermal systems: Insights from a novel multiphase hydrothermal flow model in the system $\mathrm{H}_{2} \mathrm{O}-\mathrm{NaCl}$. Transp. Porous Media 2021, 136, 65-102. [CrossRef]

104. Daubeny, C. A Description of Active and Extinct Volcanoes; Cambridge University Press: Cambridge, UK, 1826 ; pp. 168-172.

105. Ballaert, W. Origin of Salt Deposits. Proc. Brit. Assoc. Adv. Sci. 1852, 2, 100.

106. Darwin, C. The Structure and Distribution of Coral Reefs. Being the First Part of the Geology of the Voyage of the Beagle, under the Command of Capt. Fitzroy, R.N. during the Years 1832 to 1836; Smith Elder and Co. Geological Observations: London, UK, 1842; Volume 3, p. 235.

107. Roy, A.B. Fundamentals of Geology; Narosa Publishing House Pvt. Ltd.: Oxford, UK, 2010; p. 149.

108. Stober, I.; Bucher, K. Hydraulic conductivity of fractured upper crust: Insights from hydraulic tests in boreholes and fluid-rock interaction in crystalline basement rocks. Geofluids 2015, 15, 161-178. [CrossRef]

109. Singh, H.; Cai, J. Permeability of fractured shale and two-phase relative permeability in fractures. In Encyclopedia of Electrochemical Power Sources; Elsevier: Amsterdam, The Netherlands, 2019. 